\title{
Advanced training of tax consultants
}

\author{
Farida F. Adigamova ${ }^{1 \mathrm{a}}$ \\ ${ }^{1}$ Kazan Federal University, 4, Butlerov st., Kazan, 420012, Russia
}

\begin{abstract}
The purpose of the research is to review and analyze the data on the necessity to provide an educational environment for training and advanced training of tax consultants in Russia. The article considers the types of tax consulting, the historical background of training financiers in Russia, as well as identifies conditions determining the significance of tax consulting. The research establishes the connection between the negative attitude to tax payment and tax evasion. The advanced training of tax consultants should be a continuous process as they need to take into account both external and internal taxpayers risks associated with the development of law and law-enforcement practice. Obviously, the training of tax consultants should take into account the experience of developed foreign countries, such as Germany, Austria, Czech Republic, Slovakia and other European countries as well. In Russia, it is necessary to open educational institutions, which will not only be involved in the certification of tax consultants, but also provide training courses. These courses should contribute to constant increase of tax consultants knowledge, consider the tax treatment of economic activities, as well changes in the legislation, economics, finance, accounting, manufacturing processes, which will improve the quality of services provided by tax consultants.
\end{abstract}

Keywords: Tax consultant; education; taxation; training; qualification; selfstudy.

\section{Introduction}

Tax consulting is an important area of taxation, it can provide legal support to organizations on various issues related to tax payments and application of legal means to the latter.

Tax consulting allows to stabilize solvency and financial stability, which are essential characteristics of an enterprise financial and economic activity. If a company is financially stable and solvent, it has priority over other business units in attracting investment, obtaining loans, selecting suppliers and recruiting qualified personnel. In addition, the

\footnotetext{
a Corresponding author: ff104@mail.ru
} 
company does not collide with the state concerning tax remissions, payroll, dividends, repayment of loans and interests.

\section{State of tax consulting in Russia}

It should be noted that qualified professionals, involved in tax consulting, must constantly improve their skills. Dynamically developing legislation, law enforcement practices as well as constant monitoring requires the development of relevant and close to the existing reality advanced training programs.

The article considers the types of tax consulting, the historical background of training financiers in Russia, identifies conditions determining tax consulting significance as well as the importance of tax consultants advanced training.

It is important to consider that tax consulting does not fall into the competence of tax authorities. Moreover tax consultant is not a substitute for state tax control, including tax audits by the Russian Federal Tax Service agencies, using different technologies, [5,14]. Public bodies view tax consultants as trusted aides. Dedicated work of tax consultants will eliminate the problem of untimely tax payments, as well as law offences.

Tax consultant additional training depends on where a qualified tax professional is operating. It is possible to distinguish between internal and external consultation. Internal consulting is implemented by a taxes and levies consultant or by an enterprise tax department. External consulting is carried out by professionally trained consulting organizations or individuals trained in accredited training centers having a tax consultant qualification certificate. (Fig.1).

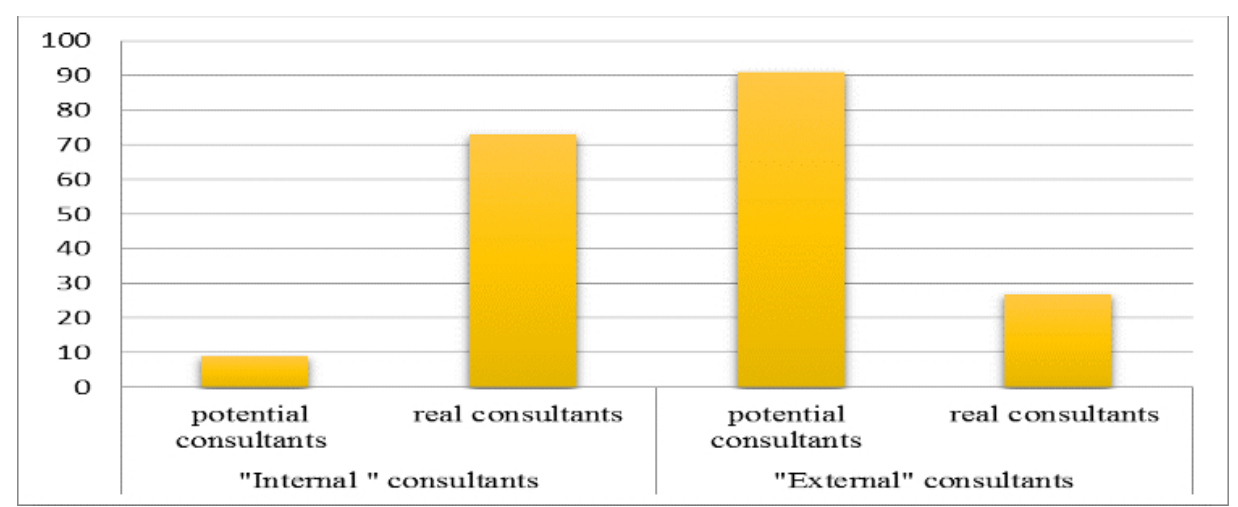

Fig.1. The ratio of "external" and "internal" tax consultants in Russia: potential consultants and real consultants

At present, almost every social sphere possesses its own kind of consulting and taxation is no exception, so it is necessary to conduct training on taxation, taking into account economic activities, such as oil, construction, agriculture, industry, innovation, insurance, banking and others. The detailed discussion of this issue is provided in the articles by [3, $4,5,1,11,10$ and 7$]$

Currently a tax consulting industry attracts almost all certified tax consultants working as accountants, economists, etc. But essentially tax consulting is still in its infancy in Russia. This fact provokes many problems and difficulties on the way of its development.

In Russia, tax consulting started its development in 2000s, while in Germany tax consulting has been expanding in terms of quality and quantity for over 50 years (Tax consultant board official site)(Fig. 2). In the Czech Republic, tax consulting occurred earlier than in the Russian Federation, however, one can observe slower growth in the number of 
tax consultants. The reason may consist in the degree of successfully passed qualifying examinations (the percentage of applicants who have passed the exam is $15-30 \%$ ).

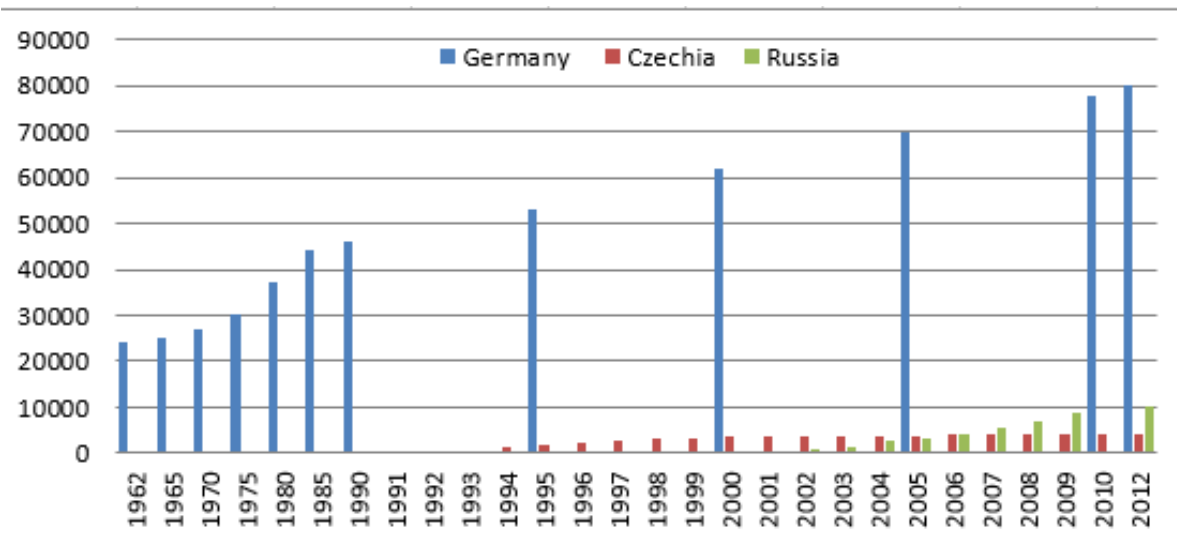

Fig.2. Number of tax consultants in Germany, the Czech Republic and Russia.

The problem of financiers training in Russia is discussed in the article of [9], initial training of tax consultants in Russia is investigated in the paper of, [1]..

In Russia the services of consultants are mainly employed by large enterprises, as small and medium business, as well as citizens simply do not have available funds to pay for their advice. Tax consultants are an expensive service. Large enterprises often have the opportunity to employ a tax professional, whereby they do not require consulting services. Based on everything mentioned above it can be concluded that it is necessary to implement a number of measures to address the problems in the field of tax consulting. In our opinion, the adoption of legislation governing the tax consulting in Russia is the only right step that can serve as an incentive for the activity development. It becomes apparent that the initial and advanced tax consultants training, as well as their activities affect the interests of different groups, organizations, and the state as a whole.

\section{Results and Discussion}

The necessity and public utility of taxpayers' consultation according to their individual needs, with regard to economic activity and specific situations in Russia are determined by the following conditions:

- Dynamic regulatory control over taxation terms, which leads to a legislation complication, tax rules understanding reduction and lack of taxpayers' rapid adaptation to changing conditions.

- Need of the taxpayer for individual professional assistance in calculating tax liability in relation to specific problems in economic activities and under the prevailing conditions of his work provided by a qualified tax consultant, which is an important factor for tax abuse prevention.

- Intensity of the consultation process (as opposed to passive provision of information and services prescribed by the law on execution of actions and functions), which suggests a reasonable prevention of tax burden growth and tax payment cost optimization under the current legislation.

- Complex and diverse approach to tax problems solution by combining many areas of professional knowledge (law, economics, finance, accounting, manufacturing processes). 
It should be emphasized that tax consultants must possess many skills and not only in the field of taxation. They must be knowledgeable in the areas of law, economics, finance, accounting, production processes and constantly improve their skills in all these areas.

As a part of the author's opinion poll respondents were asked to give major tax evasion reasons. (Fig. 3).

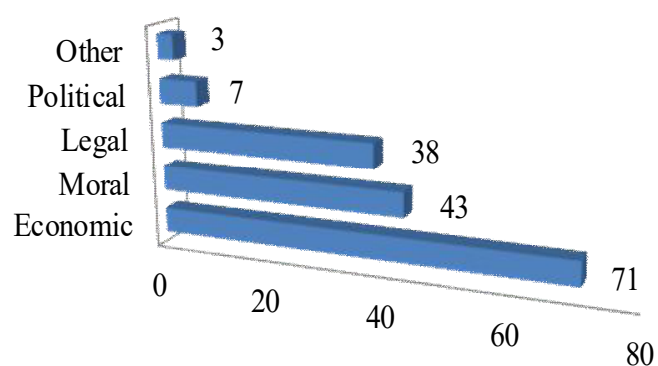

Fig. 3. Groups of motives causing tax evasion ( $\%$ of respondents).

As it can be seen from the chart, economic, moral (lack of commitment to tax liabilities), legal reasons (the complexity of the tax system, an ambiguous understanding of tax rules) are stated among the most important motives and they could be somewhat addressed by a qualified tax consultant.

The extent of tax evasion is largely dependent on public condemnation or, conversely, the approval of this phenomenon. In this regard, within the framework of the author's opinion poll respondents were asked how tax evasion affected the reputation of taxpayers in different population groups (Table. 1).

Table 1. Effect of tax evasion on the reputation of taxpayers

\begin{tabular}{lcccc}
\hline Tax evasion impact on tax payer reputation & $\begin{array}{l}\text { Difficult to } \\
\text { answer }\end{array}$ & $\begin{array}{l}\text { Negative } \\
\text { impact }\end{array}$ & $\begin{array}{c}\text { No } \\
\text { impact }\end{array}$ & $\begin{array}{l}\text { Positive } \\
\text { impact }\end{array}$ \\
\hline Among business partners & 9 & 41 & 47 & 3 \\
Among tax authorities and other governmental bodies & 5 & 83 & 10 & 2 \\
In society in general & 15 & 34 & 49 & 2 \\
\hline
\end{tabular}

Strengthening a negative attitude towards tax evasion could reduce the extent of this phenomenon. At the same time, the question of tax evasion moral evaluation is not as straightforward as it might seem at first glance. The tax authorities adhere to the position that tax evasion is evil.

Tax awareness varies according to age, income and education level of respondents (taxpayers). Better educated and wealthier citizens are more aware of the taxes they should pay. It should be noted that Russian citizens are less tolerant to business leaders, who evade paying taxes, rather than to ordinary workers, cheating the state. Thus, $57 \%$ of respondents condemn big businesses evasion, and only 39\% condemn their fellow citizens (Fig.4). 


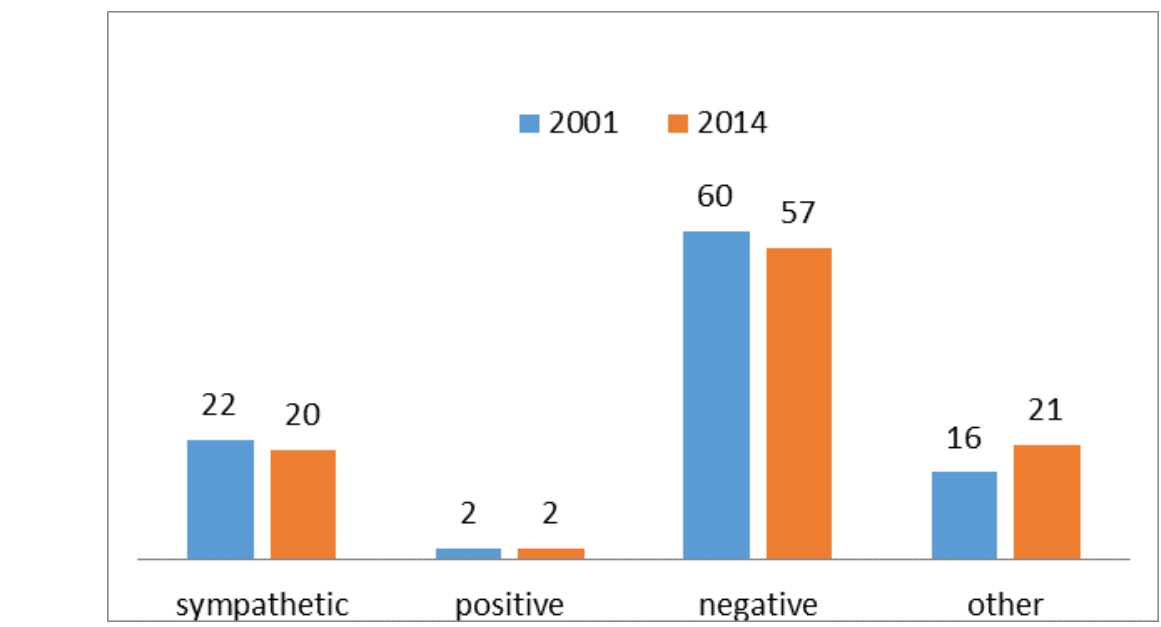

Fig.4 Attitude to business leaders tax evasion in 2001 and $2014, \%$.

Building civilized relationships between the state and taxpayers is a daunting task, which solution is possible only by tax culture enhancement, where tax consultants can provide significant assistance (Table 2.).

Table 2. Tax consulting role in tax culture enhancement.

Simplification of the tax legislation of the Russian Federation

Improving the mechanism for resolving tax disputes

Significant increase in the efficiency of tax authorities interaction with taxpayers

Raising awareness

Publicity using mass media

Promotion of tax culture, discipline and responsibility

Improving tax procedures quality

Enhancing the image and prestige of working in tax authorities

As can be seen from the table, tax consulting can provide essential support for tax culture improvement. This indicates that tax consulting will be beneficial not only for the taxpayer but also for the state as a whole.

Experts estimate that Russia needs about 150,000 tax consultants. We have developed a progression to find out when it would be possible to achieve the required number of tax consultants. According to our calculations, the achievement of the required number of tax consultants could happen in 2151 . This is a fairly distant future. To bring a date forward, tax consultation development should be fueled and promoted. To achieve this objective, new educational institutions should be opened which will not only certify tax consultants, but also conduct various training courses that contribute to constant increase of tax consultants' competence, and as a consequence, improve the tax consultancy quality.

With the help of a linear trend we calculated predicted values in the tax consultants' number for Russia in the period of 2015-2018. The following numbers were obtained: in 2015 there will be presumably 13940 tax consultants, in $2016-15810,2017-17680$, in 2018 the number of tax consultants will reach 19,550, which is almost 2 times more than in 2012. 
Everything indicates that we should closely relate to educational organizations that train tax consultants and provide advanced training as well. The number of these institutions should increase as well as the quality of the educational services rendered.

\section{Conclusion}

Thus, tax consulting plays an important role in countering tax system adverse trends development. Tax consultants offering taxpayers fee-based services, contributes to a better tax compliance of the latter. Independent advice suggests guarantee that the consultant, given all his competence, by his active, prudent advisory influence protects the client both from taxes overpayment and underpayment. The system is beneficial for the tax authorities as well. Experience shows that good tax advice depends on the tax consultants who constantly improve their qualifications either by themselves or in educational centers.

\section{References}

1. Adigamova, Farida F., Safiullin, Marat A., Tufetulov, Aidar M., Mechanism of State Tax Regulation in the Global Economy. Mediterranean Journal of Social Sciences 5 (24), 193-200, (2014).

2. Adigamova, Farida F., Tufetulov, Aidar M., Training of Tax Consultants: Experience and Prospects. Procedia - Social and Behavioral Sciences, 152, 1133-1136, (2014).

3. Galimardanova, Yu.M., Khafizova, A.R., Salmina, S.V., The Necessity for Taxable Capacity Assessment for the Segments of the Insurance Market. Mediterranean Journal of Social Sciences 5 (24), 407-412, (2014).

4. Khafizova, A.R., Fassakhov, I. A., Development of the Oil Companies Taxation System. Mediterranean Journal of Social Sciences, 6 (1), 21-24, (2015).

5. Khafizova, A.R., Galimardanova, Yu.M., Salmina, S.V., Tax Regulation of Activity of Agricultural Commodity Producers. Mediterranean Journal of Social Sciences, 5 (24), 421-426, (2014).

6. Official site of the Board of tax consultants. URL: www.palata-nk.ru. Date view: 15.04.2015, (2015).

7. Orlova, M., Khafizova, A., The tax component of innovative activity assessment in the Russian Federation. Life Science Journal, 11 (11), 328-333, (2014).

8. Sabitova, N.M., Khafizova, A.R., Information technologies as a factor of evolution of tax administration. Mediterranean Journal of Social Sciences, 6 (1), 169-173, (2015).

9. Sabitova, Nadiya M., Current issues of financial education in Russia. Procedia - Social and Behavioral Sciences, 152, $911-915$, (2014).

10. Valitov, Sh.M. Tufetulov, A.M., Yartiev, A.F., Effect of crude quality on crude oil refining efficiency. Neftyanoe Khozyaistvo - Oil Industry, 12, 132-135, (2012).

11. Yartiev, A.F., Tufetulov, A.M., Effect of license holder's cost-flow on long-term development of oil industry. Mediterranean Journal of Social Sciences, 5(24), 417-420, (2014). 